July 1984

\title{
Post Psychotic Depression in a Patient who Castrated Himself
}

Harvey Stabinsky, MD, JD

Albert Einstein School of Medicine

Susan Stabinsky, MD

Albert Einstein College of Medicine

Alfred Wiener, MD

Albert Einstein School of Medicine

Follow this and additional works at: https://jdc.jefferson.edu/jeffjpsychiatry

Part of the Psychiatry Commons

Let us know how access to this document benefits you

\section{Recommended Citation}

Stabinsky, MD, JD, Harvey; Stabinsky, MD, Susan; and Wiener, MD, Alfred (1984) "Post Psychotic

Depression in a Patient who Castrated Himself," Jefferson Journal of Psychiatry. Vol. 2 : Iss. 2 , Article 7. DOI: https://doi.org/10.29046/JJP.002.2.006

Available at: https://jdc.jefferson.edu/jeffjpsychiatry/vol2/iss2/7

This Article is brought to you for free and open access by the Jefferson Digital Commons. The Jefferson Digital Commons is a service of Thomas Jefferson University's Center for Teaching and Learning (CTL). The Commons is a showcase for Jefferson books and journals, peer-reviewed scholarly publications, unique historical collections from the University archives, and teaching tools. The Jefferson Digital Commons allows researchers and interested readers anywhere in the world to learn about and keep up to date with Jefferson scholarship. This article has been accepted for inclusion in Jefferson Journal of Psychiatry by an authorized administrator of the Jefferson Digital Commons. For more information, please contact: JeffersonDigitalCommons@jefferson.edu. 


\title{
CLINICAL CASE REPORTS
}

With this article we inaugurate our efforts to expand the scope of the Journal beyond the walls of Jefferson. We thus open the Journal to residents of all programs and invite them to share their clinical experience and research. Circulation will include contributing programs.

\section{POST PSYCHOTIC DEPRESSION IN A PATIENT WHO CASTRATED HIMSELF}

\author{
HARVEY STABINSKY, M.D., J.D. \\ SUSAN STABINSKY, M.D. \\ ALFRED WIENER, M.D.
}

\section{Introduction}

The differential diagnosis of psychosis associated with depression includes schizophrenia, schizoaffective and major affective disorders. Depression associated with schizophrenia may be a prominent feature of the patient's early presentation (1), or manifest itself only as the psychotic symptoms resolve $(2,3)$. Neuroleptics may play a causal role in the development of post-psychotic depression. This drug effect may be linked to genetic factors (4).

In the following case, the patient presented in a floridly psychotic state after having castrated himself. Depression did not appear to be a prominent feature of his initial presentation. Only later in the course of his treatment did depressive symptoms manifest themselves.

\section{Case Report}

The patient was a thirty-seven-year-old man who was admitted to a surgical service after having amputated his penis two centimeters distal to the penile-scrotal junction. He stated that he had done so because he believed that there was an ongoing intergalactic war between the forces of good and evil in which he might have to oppose his father (who, in reality, had been dead for seven years). As a result, the patient castrated himself "to remain neutral." To do so, he reported having to use two knives because the first was too dull. During the act he denied feeling any pain. Indeed, he

Drs. Harvey and Susan Stabinsky are Chief Residents in Psychiatry at Montefiore Medical Center of the Albert Einstein School of Medicine, Bronx, New York.

Dr. Weiner is an Assistant Clinical Professor of Psychiatry at the same institution. 
reported anticipating no difficulties following his castration and summoned emergency aid only when he experienced unexpected bleeding.

The patient was first seen by the psychiatric consultation service on an emergency basis after he refused reimplantation of his penis, saying that he would prefer to live with the consequences of not having sexual intercourse and being unable to urinate in a standing position. After being judged to be incapable of exercising sufficient judgement to consent to or refuse medical procedures, the patient received reimplantation surgery on the day of admission.

Thereafter the patient was followed by the psychiatric consultation service, beginning while he was still in the recovery room. It was learned that the patient had no previous psychiatric contacts, although he had a long-standing history of auditory hallucinations, paranoid ideation, and ideas of reference. He reported having immigrated to this country at the age of nineteen. Subsequently, he became a student, teacher, and performer of classical music at a prestigous institution. During the last five years he reported becoming increasingly less functional. He had lost his interest in music and was supporting himself by working as a messenger. Concomitantly he reported an exacerbation of his paranoia and hallucinations.

In addition to recommending neuroleptic medication for the patient, the liaison team attempted to help the floor staff work through their horrified and fearful reactions (5). Over the period of a month a dramatic change was noted in the attitude of the floor staff, as evidenced by their staying late to assist in his care and requests for several meetings to discuss his case and prognosis.

By the fourth week of his hospitalization the patient was remarkably less psychotic, but had become increasingly withdrawn, apathetic, and melancholic. Ultimately he began to express suicidal wishes and ceased participating in his care. A dexamethasone suppression test (DST) was performed that showed a baseline plasma cortisol level of $19.3 \mathrm{mcg} \%$, with a repeat level of $20.4 \mathrm{mcg} \%$ following the administration of one mg of dexamethasone. Subsequently, the patient was begun on imipramine in gradually increasing doses of up to $250 \mathrm{mg}$ per day. Three weeks later a second DST was performed, revealing a pre-dexamethasone level of $14.3 \mathrm{mcg} \%$ and a post-dexamethasone level of $9.7 \mathrm{mcg} \%$. At this point, the patient had demonstrated no clinical response to imipramine, remaining despondent and expressing the wish to die.

The patient was maintained on imipramine. A third DST was obtained sixteen days later. During this period of time, the patient became noticeably less depressed, more concerned with the future, and consented to become reinvolved with his care. Furthermore he displayed no evidence of psychosis. Results of his third DST were a pre-dexamethasone level of $5.8 \mathrm{mcg} \%$ and a post-dexamethasone level of $3.9 \mathrm{mcg} \%$.

Two weeks later a fourth DST revealed a pre-dexamthasone level of $4.8 \mathrm{mcg} \%$ and a post-dexamethasone level of $3.2 \mathrm{mcg} \%$. The patient continued to show improvement commensurate with the change in his DST. He consented to several surgical revisions, eagerly participated in grand rounds, and, four months after admission, agreed to be transferred to an inpatient psychiatric unit for further treatment. Two months later the patient was able to be discharged home off medication, without evidence of either psychosis or depression. 


\section{Discussion}

Auto-castration has been associated with transsexualism (6), focal suicide (7), refusal of elective surgery (8), various delusions $(7,9)$, command hallucinations $(10)$, and possibly psychotic depression (11). Although our initial clinical impression was that this patient's signs and symptoms were most consistent with the diagnosis of schizophrenia, as his psychotic symptoms resolved, depression became an increasingly prominent feature of his presentation. It is our belief that this depression represented a post-psychotic phenomenon.

This case suggests that serial DSTs (12) may be useful in the evaluation and management of depression, especially in instances when an admission diagnosis may serve to camouflage a secondary diagnosis of depression. Furthermore the correlation between this patient's apparent response to imipramine and the change in the results of his DSTs suggests that this test may be useful in evaluating a patient's response to treatment as well.

\section{REFERENCES}

1. Knights A, Hirsch SR: 'Revealed' depression and drug treatment for schizophrenia. Arch Gen Psych 38: 806-811, 1981

2. McGlashan TH, Carpenter WT: An investigation of the post-psychotic depression syndrome. Am J Psych 133: 14-19, 1976

3. Hirsch SR: Discussion: The causality of depression in schizophrenia. Brit J Psych 142: 624-625, 1983

4. Galdi J, Rieder RO, Silber D, Bonato RR: Genetic factors in the response to neuroleptics in schizophrenia: A psychopharmacogenetic study. Psychol Med 11: 713-728, 1981

5. Greilsheimer H, Groves JB: Male genital self-mutilation. Arch Gen Psych 36: 441-446, 1979

6. Haberman MA, Michael RP: Autocastration in transsexualism. Am J Psych 136: 347-348, 1979

7. Pabis R, Mirla MA, Tozmans S: Autocastration as a counterphobic focal suicide. Suic Lf Th Bvr 11: 3-9, 1981

8. Kalin NH: Genital and abdominal self-surgery. A case report. JAMA 241: 2188-2189, 1979

9. Money J, De-Priest M: Three cases of genital self-surgery and their relationship to transsexualism. J Sex Rsch 12: 283-294, 1976

10. Hall DC, Lawson BZ, Wilson LG: Command hallucinations and self-amputation of the penis and hand during a first psychotic break. J Clin Psych 42:322-324, 1981

11. Pabis R, Mirza MA, Tozman S: A case study of auto-castration. Am J Psych 137: 626-627, 1980

12. Carroll BJ, Feinberg M, et al: A specific laboratory test for the diagnosis of melancholia. Arch Gen Psych 38:15-22, 1981 


\title{
PSYCHOSIS IN A PATIENT WITH AUTOIMMUNE DEFICIENCY SYNDROME
}

\author{
VIVIAN CHARNECO, M.D.
}

\section{Introduction}

Autoimmune deficiency syndrome (AIDS) is a disease whose incidence has grown precipitously in recent years. Its victims face social and psychological isolation (1). Contributing to this isolation is the fear of contact with AIDS patients that exists among health care workers and the public (2).

Increasingly more is being understood about this mysterious disease. Recent reports have supported a viral etiology. The chief criterion for diagnosis is an inverted helper to suppressor T-cell ratio. Other supportive findings include lymphopenia, leukopenia, elevated IgA levels, and anergia. The following case report highlights the neurological and psychiatric symptoms that may be seen in a patient with AIDS.

\section{Case Report}

The patient was a 48-year-old male with no prior psychiatric history. He was brought to a psychiatric emergency room by his family, who complained of a three day history of increasing insomnia and agitation, as well as an unusual preoccupation with working in his basement. About four hours prior to presentation the patient was noted to have become increasingly disorganized, was speaking incoherently, and began engaging in purposeless behavior such as banging his head against the tub. When the patient's family tried to stop him from banging his head, he became combative. Ultimately the police were called so that he could be transported to the hospital.

Further history obtained from the patient's family was significant for a ten pound weight loss over the last three months following rectal surgery for what was diagnosed as condiloma acuminata. Subsequent to this surgery, the patient developed diarrhea with secondary mild hypokalemia. Additionally he had a long standing history of hypertension. During the three weeks prior to presentation he was reported to have suffered from an upper respiratory infection associated with occasional coughing. The family denied any history of drug and alcohol abuse, or homosexual activity. Prior to this sudden change in his behavior, the patient had been attending his job as a maintenance worker regularly.

Initial mental status examination was remarkable for an agitated, uncooperative male who was disoriented in all spheres and was mumbling incoherently. He displayed echolalia, stared off into space purposelessly, and postured in bizarre manners at times. An attempt to evaluate his cognition was unsuccessful.

The patient was treated with $10 \mathrm{mg}$. of haloperidol given intramuscularly in an

Dr. Charneco is third-year resident in psychiatry. 
attempt to control his agitated behavior. He responded well, becoming remarkably less agitated. Within eight hours his sensorium began to clear. He became increasingly oriented, was goal-directed in his behavior, and began to have partial recall of events from earlier in the day.

Concomitant medical workup revealed an oral temperature of $103^{\circ} \mathrm{F}$. A complete blood count with differential and serum electrolyte values were within normal limits except for a potassium level of $2.8 \mathrm{mEq} / \mathrm{L}$. Drug screen was negative. A chest X-ray revealed a diffuse pulmonary infiltrate, and at that time the patient was admitted to the medical service. Subsequent bronchoscopy revealed Pneumocystis carinii. Later studies revealed $2 \% \mathrm{~T}$-cell helper (normal range $45 \% \pm 11 \%$ ) and $66 \% \mathrm{~T}$-cell suppressor (normal range $28 \% \pm 8 \%$ ) concentrations.

Two days after admission a psychiatric evaluation revealed no remarkable mental status abnormalities, in contrast to his initial presentation. The psychiatric consultation team continued to follow this patient, who displayed no further evidence of psychosis, although he became very anxious when he was told that he had autoimmune deficiency syndrome some nine days after admission.

\section{DISCUSSION}

Neurologic and psychiatric symptoms are sometimes found in patients with AIDS. Two patterns of neurological involvement have been described (3). One is characterized by symptoms of focal disease, and may be attributed to specific etiologic agents such as Toxoplasma (4). Bedri and Weinstein have described an AIDS patient who developed progressive multifocal leukoencephalopathy whose symptoms included confusion, gait disturbance, urinary incontinence, memory and attention deficits (5). These symptoms are among those described by the American Neurological Association that can be associated with AIDS (3). Other notable symptoms are progressive dementia, seizures, inappropriate antidiuretic hormone secretion, hallucinations, parasthesias, paresis, and coma vigil. While in some instances a focal etiology may be described, in others no neuropathological changes can be correlated with the symptoms. In those patients who characteristically present with psychiatric symptoms, no focal pathology may exist, although a higher percentage of microglial nodules and Alzheimer type II cells has been found in some of these patients' brains (3).

In the patient presented there was no recurrence of psychiatric symptoms despite repeated temperatures as high as $103^{\circ} \mathrm{F}$. Because no further neurological workup was done, no conclusive statements can be made as to the etiology of his agitated behavior. It is tempting to suggest that his symptoms, which may have been attributable to septicemia, were the result of non-focal involvement of the CNS. In any event, it behooves us as psychiatrists to have a fuller understanding of how AIDS may effect or present in the patients we treat.

\section{REFERENCES}

1. Holtz H, Dobro J, et al: Psychosocial impact of acquired immune deficiency syndrome. JAMA 250: 167, 1983 
2. Weiss K: AIDS: Turmoil in the medical profession. The New Phys 32: 13-17, 1983

3. Gapen P: Neurological complications now characterizing many AIDS victims. JAMA 248: 2941-2942, 1982

4. Post MJ, Chan JC: Toxoplasma encephalitits in Haitian adults with acquired immunodeficiency syndrome: a clinical, pathologic CT correlation. Am J Roen 140: 861-868, 1983

5. Bedri J, Weinstein W, et al: Progressive multifocal leuko-encephalopathy in acquired immunodificiency syndrome. New Engl J Med 309: 492-493, 1983 